\title{
ASBESTOS EXPOSURE AMONG TRANSMISSION MECHANICS IN AUTOMOTIVE REPAIR SHOPS
}

\author{
Natalia Salazar (1), María Fernanda Cely-García (1), Patrick Breysse (2), Juan Pablo Ramos-Bonilla (1)
}

(1) Department of Civil and Environmental Engineering, Universidad de los Andes, Bogotá, Colombia.

(2) Division of Environmental Health Engineering, Bloomberg School of Public Health, Johns Hopkins

University, Baltimore, Maryland

\begin{abstract}
Introduction: Asbestos have been used in a broad variety of industrial products, including clutch discs of the transmission system of vehicles. Studies conducted in high-income countries that have analyzed personal asbestos exposures of transmission mechanics have concluded that these workers are exposed to asbestos concentrations in compliance with the U.S. Occupational Safety and Health Administration (U.S. OSHA) occupational standards.

Clutch facings are the friction component of clutch discs. If clutch facings are sold separated from the support, they require manipulation before installation in the vehicle. The manipulation of asbestos containing clutch facings is performed by a group of mechanics known as riveters, and includes drilling, countersinking, riveting, sanding, and occasionally grinding, tasks that can potentially release asbestos fibers, exposing the mechanics. These manipulation activities are not reported in studies conducted in high-income countries. This study analyzes personal asbestos exposures of transmission mechanics that manipulate clutch facings.
\end{abstract}

Methods: Air sampling campaigns in two transmission repair shops (TRS) were conducted in November 2012 and July 2013 in Bogotá, Colombia. Four workers employed in these TRS were sampled (i.e., three riveters and one supervisor). Personal samples $(n=39)$, short-term personal samples $(n=49)$, area samples $(n=52)$, blank samples $(n=8)$, and background samples $(n=2)$ were collected on both TRS during 3 to 5 consecutive days, following U.S. National Institute for Occupational Safety and Health (U.S. NIOSH) methods 7400 and 7402 . Asbestos samples were analyzed by an American Industrial Hygiene Association (AIHA) accredited laboratory.

Results: In at least one of the days sampled, all riveters were exposed to asbestos concentrations not in compliance with the U.S. OSHA permissible exposure limit (U.S. OSHA PEL) or the Colombian permissible limit value (PLV). Additionally, from the forty seven 30-min short-term personal samples collected, two (4.3\%) were not in compliance with the U.S. OSHA short-term exposure limit (U.S. OSHA STEL) of $1 \mathrm{f} / \mathrm{cm}^{3}$.

Conclusions: This study suggests that transmission mechanics that manipulate asbestos containing clutch facings are exposed to extremely high asbestos concentrations, and could be at excess risk of developing asbestos related diseases.

Keywords: Asbestos, chrysotile, clutch disc, transmission mechanics, Colombia, exposure assessment 


\section{INTRODUCTION}

Asbestos are good acoustic, heat and fire insulators, and resist thermal, biological and chemical attack (Thompson \& Mason, 2002). Because of these characteristics, asbestos have been used in a broad variety of industrial products such as friction products (e.g., brake and transmission products of vehicles), building materials, and heat-resistant textiles (Pierce, et al., 2008).

A causal association between asbestos exposure and several diseases has been established (IARC, 1998). The International Agency for Research on Cancer (IARC) has classified all types of asbestos (i.e., chrysotile and amphiboles) as carcinogenic to humans (Group I) (IARC, 1998). Some of the diseases that might result from the inhalation of asbestos fibers include lung cancer, asbestosis, and mesothelioma (Kanarek, 2011; Liu et al., 2013). Every year asbestos are responsible for half of the occupational cancer deaths worldwide (OMS, 2004).

In 2011, the Colombian Ministry of Social Protection established for the first time an asbestos occupational standard (i.e., Resolution 007, 2011) (MSPS, 2011). In Resolution 007, the American Conference of Governmental Industrial Hygienists (ACGIH) threshold limit value (TLV) for asbestos was adopted as the Colombian permissible limit value (PLV). Thus, the Colombian PLV is $0.1 \mathrm{f} / \mathrm{cm}^{3}$ for an 8-hr time weighted average (TWA) phase contrast microscopy equivalent (PCME) asbestos concentration. In the United States, the Occupational Safety and Health Administration (U.S. OSHA) permissible exposure limit (U.S. OSHA PEL) for asbestos is $0.1 \mathrm{f} / \mathrm{cm}^{3}$ for an 8-hr TWA PCME concentration. The U.S. OSHA has also established a short-term exposure limit (U.S. OSHA STEL) of $1 \mathrm{f} / \mathrm{cm}^{3} \mathrm{PCME}$ asbestos concentration for a 30-min exposure period (OSHA, 2013).

Asbestos containing clutch parts have been used since the early twentieth century (Jiang, et al., 2008; Cohen \& Van Orden, 2008). Traditionally, chrysotile was the type of asbestos used in clutch parts, comprising $30 \%$ to $60 \%$ of the material (Jiang, et al., 2008; Yeung, et al., 1999). Amphiboles have not been detected in previous studies of transmission mechanics (Blake et al., 2008; Jiang, et al., 2008). Beginning in the 1980s, chrysotile was gradually replaced in clutch products used in the United States with other acceptable substitutes (Jiang, et al., 2008).

In 1975, the United States National Institute for Occupational Safety and Health (U.S. NIOSH) warned about the potential risk of asbestos exposure of workers that handled asbestos containing brake parts and clutch discs (NIOSH, 1975). Several exposure assessment studies conducted in Australia and the United States have concluded that transmission mechanics are exposed to asbestos concentrations in compliance with both the U.S. OSHA PEL and STEL (Blake et al, 2008; Boelter et al., 2007; Cohen y Van Orden, 2008; Jiang et al., 2008; Yeung et al., 1999). These studies describe that the activities performed by transmission mechanics only involve removing the entire old clutch disc and replacing it with a new one (Blake et al., 2008; Cohen \& Van Orden, 2008; Boelter et al., 2003).

A previous study of our research group conducted on brake mechanics in Bogotá found that the manipulation of asbestos containing brake products resulted in the release of important amounts of asbestos fibers, exposing the workers (Cely-García, et al., 2012). Transmission mechanics could be facing a similar situation, since asbestos containing clutch facings (i.e., the friction component of clutch discs), are commercialized in Colombia detached from the clutch plate (i.e., metallic support). The clutch disc is composed by two clutch facings attached to the clutch plate, and clutch facings that are detached from the plate require manipulation before installation. The current study analyses personal asbestos exposures of transmission mechanics during the manipulation process of asbestos containing clutch facings. 


\section{METHODS}

In 2012, a comprehensive and detailed database of brake repair shops located in an area of the city of Bogota that clusters automotive repair shops was developed. During the development of this database, three transmission repair shops (TRS) were identified. Two of these shops (i.e., TRS1 and TRS2) collaborated with this study. The study methods and design were approved by the Ethics Committee of Universidad de los Andes, and workers from the TRS that participated in the study signed an informed consent.

Personal, short-term personal, area, and quality control air samples were collected during 3 consecutive days in TRS1 (Nov 8-10, 2012), and 5 consecutive days in TRS2 (July 11-15, 2013), during the entire work-shift. To reduce the chances of overloading the filters during the collection of air samples, the work-shift was divided into shorter partial-period sampling windows. Air samples collection and analysis followed U.S. NIOSH methods 7400 (NIOSH, 1994a) and 7402 (NIOSH, 1994b). U.S. NIOSH method 7400 conducts fiber counts using phase contrast microscopy (PCM), and reports total fiber concentration. U.S. NIOSH method 7402 utilizes transmission electron microscopy (TEM) to conduct fiber identification and counting, and reports both total fibers and asbestos fibers concentrations, including the type of asbestos found.

Personal samples were collected in a group of workers of the TRS known as riveters, who manipulate asbestos and non-asbestos containing clutch facings to attach them to the clutch plate before installation in the vehicle. In TRS1, there were two riveters $(R 1, R 2)$ in charge of the manipulation of clutch facings, and sporadically, depending on the amount of work, a third worker (W1) who is the supervisor of the TRS, also performed manipulations. In TRS2, the riveter (R3) conducting the manipulation processes was also the mechanic in charge of repairing the vehicle's transmission system. To avoid study-induced bias from the sampling campaign, all workers were instructed to conduct their daily activities without modifications. The activities performed by workers sampled were recorded in activities diaries. Short-term personal samples were collected during the manipulation activities of clutch facings, and during cleaning activities of the shops. The duration of the sampling windows were longer when no manipulations were conducted, since air fiber concentrations were expected to be low. Blanks samples were collected for each sampling day, and background samples were collected during one night at each shop. All personal samples were analyzed by PCM and TEM. Background and blanks samples were analyzed by PCM.

Study design and methods were similar to those applied in a previous study of our research group (Cely-García, et al., 2012). Equipment used for air sampling consisted of AIRChek XR5000 pumps (SKC-Inc., Eighty Four, PA, U.S.) operated at a flow rate of $\sim 2$ LPM, connected to sampling cassettes of $25 \mathrm{~mm}$ diameter and $50 \mathrm{~mm}$ conducting extension cowls with MCE filters of 25-mm diameter and $0.45 \mu \mathrm{m}$ pore size (SKC Preloaded Cassette, SKC-Inc., Eighty Four, PA, U.S.). Flow rates were calibrated at the beginning and the end of each sampling window using a Defender 510 High or 520 High BIOS International Calibrator (BIOS International, Butler, NJ, U.S.) following standard procedures. Samples were reported as suspect if the difference between the initial and final flow was above $5 \%$.

Samples were analyzed by Forensic Analytical Laboratories Inc. (Forensic Analytical Laboratories Inc, Hayward, CA, USA), an American Industrial Hygiene Association (AIHA) accredited laboratory that also participates in the National Voluntary Laboratory Accreditation Program (NVLAP). TEM analysis was performed at $100 \mathrm{kV}$ accelerating voltage and $\sim 2500 \mathrm{x}$ magnification to count fibers $>5 \mu \mathrm{m}$, using a Philips CM12 TEM (Eindhoven, Netherlands, installed in 1991). A magnification of $10000 x$ was used to determine fiber dimension and countability of fibers close in length to $5 \mu \mathrm{m}$. The energy dispersive $X$ ray analyzer (EDXA) instrumentation was manufactured 
by Evex (Princeton, NJ, installed in 2007), and consists of a Quantum Dot Detector (QDD) with standard window and digital ADC/MCA analyzer and Q-Dot power supply (Forensic Analitical Laboratories, 2013).

Phase contrast microscopy equivalent (PCME) personal concentrations were used for comparison purposes against both the Colombian and the U.S. OSHA standards. To estimate PCME concentrations, PCM concentrations were corrected with the fraction of asbestos fibers to total fibers (f/F) reported by TEM (NIOSH, 1994b).

The U.S. OSHA PEL and Colombian PLV set limits for asbestos personal exposures during workshifts of 8-hr per day. Nevertheless, in multiple occupations in Colombia, as it happened with the mechanics involved in the current study, the daily work-shift is longer. The approach to deal with work-shifts extending beyond 8-hr differs between the two standards (i.e., U.S. OSHA PEL and Colombian PLV). One of the options recommended in the U.S. OSHA Technical Manual is using the worst 8-hr partial period sampling windows of each work-shift to estimate the 8-hr TWA PCME concentration, for comparison purposes against the U.S. OSHA PEL (OSHA, 2008). This approach was used in the current study. For short-term personal samples, the $30-\mathrm{min}$ PCME personal concentrations were compared against the U.S. OSHA STEL of $1 \mathrm{f} / \mathrm{cm}^{3}$.

In the case of the Colombian PLV, the regulation stipulates that when the work-shift exceeds 8-hr, the PLV must be adjusted following Eq. 1 and Eq. 2 (MSPS, 2011):

$$
\begin{aligned}
& \mathrm{CF}=(8 / \mathrm{hd}){ }^{*}[(24-\mathrm{hd}) / 16] \\
& \mathrm{PLV} \mathrm{C}=\mathrm{CF}{ }^{*} \mathrm{PLV}
\end{aligned}
$$

Where:

$\mathrm{CF}$ is a correction factor hd is the number of hours worked per day PLVc is the Corrected PLV.

In TRS1 the work-shift was 8.5-hr/day, and in TRS2 was 9-hr/day. For comparison purposes against the Colombian PLV, the adjusted PLV is $0.091 \mathrm{f} / \mathrm{cm}^{3}$ for TRS 1 and $0.083 \mathrm{f} / \mathrm{cm}^{3}$ for TRS2.

When PCM concentrations were below the limit of detection (LOD), one-half of the LOD was used for calculation purposes. When work-shifts ended before 8-hr or the worker left the shop, fiber concentrations were assumed as $0 \mathrm{f} / \mathrm{cm}^{3}$ for the time remaining to complete the work-shift.

Area samples were collected in both shops at a breathing height of $1.5 \mathrm{~m}$. In TRS1 the collection of area samples was done to determine if fibers could migrate outside the manipulation area, exposing administrative staff or customers. In TRS1 the office facilities were physically separated from the manipulation area, and area samples with a duration of $\sim 4$-hr were collected at the office entrance (OF), and at the manipulation area (MA). TRS2 did not have physically separated areas, since this shop only had one large area where both administrative and repair activities were conducted. To assess fiber migration in TRS2, short-term area samples were collected at $1 \mathrm{~m}$ (A1) and $2 m$ (A2) from the manipulation equipment (i.e., emery disc), simultaneously to the short-term personal samples collected during the manipulation processes. Figure 1 shows the location of the area samples in each TRS.

All area samples were analyzed by PCM, and in TRS2, area samples collected at $1 \mathrm{~m}$ and $2 \mathrm{~m}$ during days in which the 8-hr personal concentration exceeded the U.S. OSHA PEL, were also analyzed by TEM (i.e., day 1 and day 2 ). 
a)

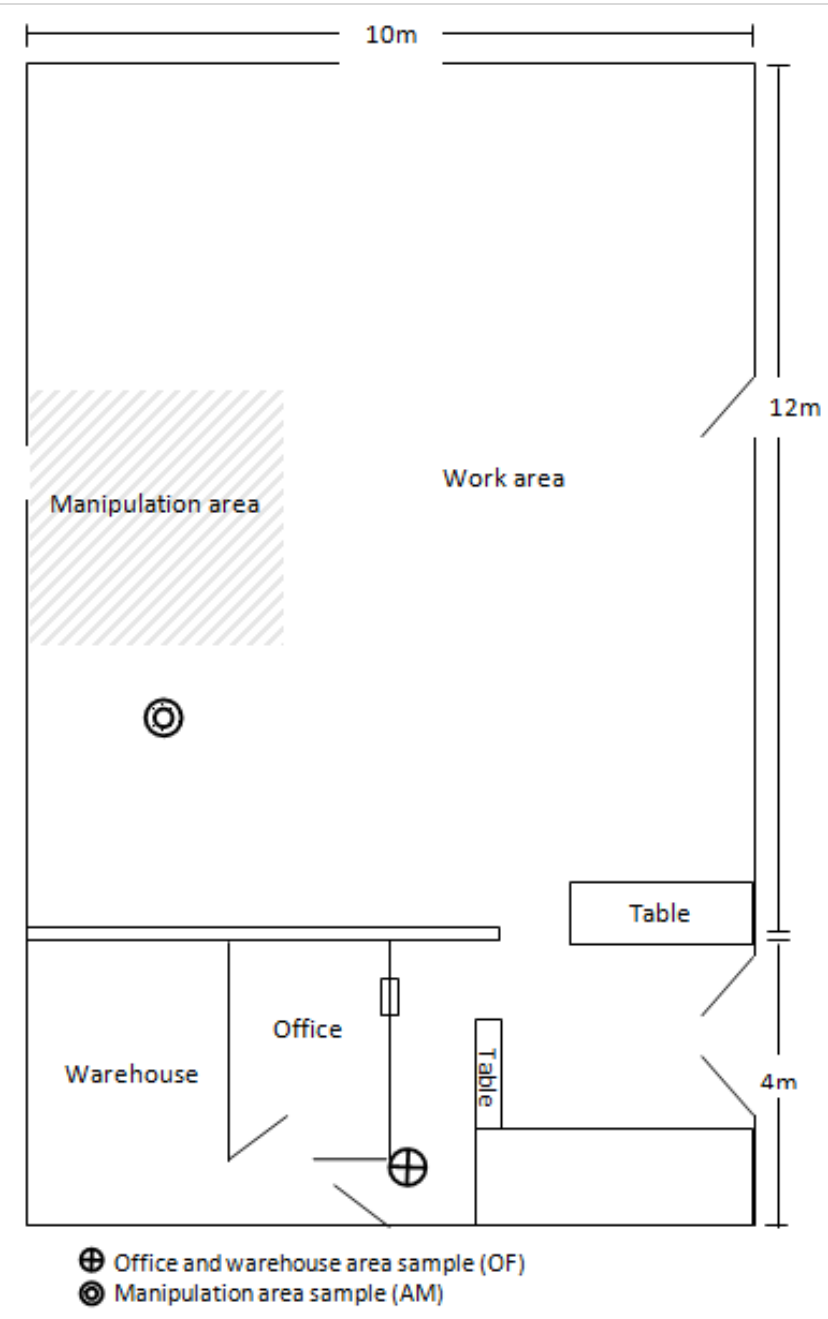

b)

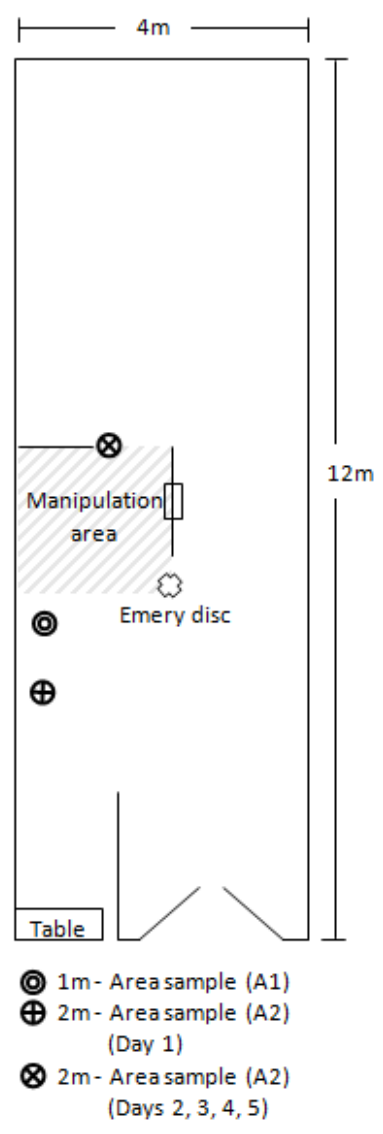

Figure 1. a) Location of area samples in Transmission Repair Shop 1 (TRS1). b) Location of area samples in TRS2.

Temperature and relative humidity were recorded on manipulation areas using a HOBO U10 Temperature Relative Humidity Data Logger U10-003 (ONSET, Bourne, MA, U.S.).

\section{RESULTS}

Description of the transmission repair shops.

TRS1 operates $\sim 8.5$-hr per day on weekdays, and 5-hr on Saturdays. TRS2 operates $\sim 9$-hr from Monday to Saturday. Both TRS use asbestos containing clutch facings, and TRS1 sporadically uses non-asbestos containing clutch facings (i.e., glass fiber). Table 1 presents a description of the TRS involved in the study.

Table 1. Description of transmission repair shops (TRS)

\begin{tabular}{lll}
\hline \multicolumn{1}{c}{ Shops Characteristics } & \multicolumn{1}{c}{ TRS 1 } & TRS 2 \\
\hline Type of vehicles serviced & $\begin{array}{l}\text { Prepares transmission parts for heavy } \\
\text { and passenger vehicles serviced at the } \\
\text { shop and at other nearby TRS. }\end{array}$ & $\begin{array}{l}\text { Prepares transmission parts for } \\
\text { passenger vehicles exclusively serviced } \\
\text { at the shop. }\end{array}$ \\
$\begin{array}{l}\text { Number of clutch discs } \\
\text { manipulated per day }\end{array}$ & $\sim 12$ & $\sim 1$ \\
\hline
\end{tabular}


Workers involved in clutch discs preparation

Area of the shop, ceiling height

Description of office and warehouse

Description of manipulation area

Manipulation equipment and materials

Ventilation system

Cleaning activities of the manipulation area

Respiratory Protection Equipment
2 Riveters (R1, R2)

1 Supervisor (W1)

$\sim 160 \mathrm{~m}^{2}$ with a ceiling height between $3.5 \mathrm{~m}$ and $4.5 \mathrm{~m}$.

Office and warehouse area of $\sim 20 \mathrm{~m}^{2}$, physically separated from the manipulation area. Warehouse access is through the office. Office door located at $\sim 10 \mathrm{~m}$ from the manipulation area.

The doors of the office and the warehouse remained open during the entire work-shift.

Area of $\sim 13 \mathrm{~m}^{2}$.

The manipulation area was embedded in a larger area where other mechanics performed their work.
1 drill
1 countersink
1 rivet machine
1 emery machine (with emery stone and emery disc)
Sandpaper

Consisted of a self-made extractor hood located above the countersink and rivet machines, which was rarely operated.

There are two skylights in the roof, one located above the manipulation area, which remained open during the sampling days. Two exit doors remained open during the entire workshift.

Every day at the end of the shift the shop was cleaned. This was done after sprinkling small amounts of water on the floor. Occasionally workers removed dust from the machines with their hand or a broom in dry conditions.

Workers wore working clothes. In some cases workers used inappropriate respiratory protection, including a piece of cloth or a filtering face-piece respirator to cover their nose and mouth.
1 Riveter (R3)

$\sim 48 \mathrm{~m}^{2}$ with a ceiling height $\sim 3.5 \mathrm{~m}$

Office and warehouse area shared space with manipulation area. Work desk located at $\sim 3 \mathrm{~m}$ from the manipulation area, close to the exit door. Exit door remained open during the entire work-shift.

Area of $\sim 4 \mathrm{~m}^{2}$ with a ceiling height of $\sim 3$ $\mathrm{m}$, which was $0.5 \mathrm{~m}$ lower than the rest of the shop.

\author{
1 drill \\ 1 countersink \\ 1 rivet machine \\ 1 emery machine (with emery stone \\ and emery disc) \\ Sandpaper
}

No ventilation system in the shop, except for the natural ventilation provided by the exit door. This door remained open during the entire workshift.

Cleaning activities under dry conditions were performed once during the sampling campaign at the end of the week.

Worker wore working clothes. The riveter used a half face-piece airpurifying respirator on top of a filtering face-piece respirator. Neither respirator met the recommendations for asbestos protection. Respirators were loose, and occasionally the nose was uncovered.

\section{Description of manipulation activities of clutch facings}

At the TRS sampled, clutch facings are sold without holes and separated from the clutch plate. Using the activities diaries kept during the sampling campaigns, it was possible to determine the tasks involved in the manipulation process required to attach clutch facings to the clutch plate. 
The manipulation process of clutch facings is the same for all types of manual transmissions (i.e., both heavy and passenger vehicles). Once the clutch disc has been uninstalled from the transmission system, the manipulation process starts with the removal of the rivets from the old clutch facings using a drill. The new clutch facings are attached to the old clutch plate using a wrench, and holes are drilled in the clutch facings matching the holes of the clutch plate. Then, the holes on the clutch facings are countersunk, and if drilling the clutch facings leaves an irregular surface surrounding the holes, the surface is sanded. In TRS2, the riveter rubbed one clutch facing against the other to remove the debris. Subsequently, the clutch facings are riveted to the plate. If the size of the facings does not match the plate, facings are ground with an emery disc.

Sometimes clutch facings for specific vehicles are not commercially available or they are not in stock. In such occasions, riveters need to adjust clutch facings of improper size to the clutch plate, which includes cutting the edges, grinding, and sanding the products. A flow-chart of the manipulation process is presented in Figure 2.

\section{Air samples results}

A total of 150 samples were collected in both TRS, including 39 personal samples of different duration, 49 short-term personal samples, 52 area samples, 8 blanks, and 2 background samples. Chrysotile fibers were the only type of asbestos identified in the samples collected in both TRS. Eleven TEM fiber counts were below the LOD. One sample was suspect because the flow drift was greater than $5 \%$ (i.e., $5.47 \%$ ). Another 3 samples were labeled as suspect because the conducting extension cowls were accidentally opened when detaching them from the pump, although the filter remained in the cowl and the cowl was immediately sealed again. One filter was reported by the laboratory as "loaded with particulates" (i.e., R1 Day1 ST 3). No fibers were found in the blanks, and both background samples collected had PCM concentrations below the LOD.

During sampling days, temperature in TRS1 ranged between $\sim 15^{\circ} \mathrm{C}$ and $\sim 24^{\circ} \mathrm{C}$ in the manipulation area, and between $\sim 19^{\circ} \mathrm{C}$ and $\sim 22^{\circ} \mathrm{C}$ in the office area. Relative humidity ranged between $\sim 36 \%$ and $\sim 70 \%$ in the manipulation area, and between $\sim 38 \%$ and $\sim 60 \%$ in the office area. In TRS2, temperature and relative humidity were sampled at $1 \mathrm{~m}$ and $2 \mathrm{~m}$ from the manipulation equipment (i.e., $\mathrm{A} 1$ and $\mathrm{A} 2$, respectively). Temperature ranged between $\sim 17^{\circ} \mathrm{C}$ to $\sim 22^{\circ} \mathrm{C}$ in both sampling points, and relative humidity ranged between $\sim 53 \%$ to $\sim 72 \%$ in sample point $\mathrm{A} 1$ and between $\sim 47 \%$ to $\sim 67 \%$ in sample point $\mathrm{A} 2$.

\section{Personal air samples results}

Table 2 presents the results of the 8-hr TWA and 8.5-hr TWA personal asbestos concentrations in TRS1, for comparison purposes against the U.S. OSHA PEL and the Colombian PLV, respectively. Both riveters sampled in TRS1 were exposed to asbestos concentrations not in compliance with both the U.S. OSHA PEL and the Colombian PLVc during the first sampling day (i.e., R1 - Day 1, R2 - Day 1), and were exposed to asbestos concentrations above $50 \%$ of the U.S. OSHA PEL and the Colombian standard during the second sampling day (i.e., R1 - Day 2, R2 - Day 2). The supervisor in TRS 1 (i.e., W1) was exposed to asbestos concentrations below both U.S. OSHA and Colombian standards in all the days sampled.

Table 3 presents the results of the 8-hr TWA and 9-hr TWA personal asbestos concentrations in TRS2. Riveter R3 was exposed to asbestos concentrations above both standards during two sampling days (i.e. R3 - Day 1 and R3 - Day 2), and was exposed to asbestos concentrations 
exceeding $50 \%$ of the U.S. OSHA PEL and the Colombian standard during day 5 (i.e., R3 - Day $5)$. 


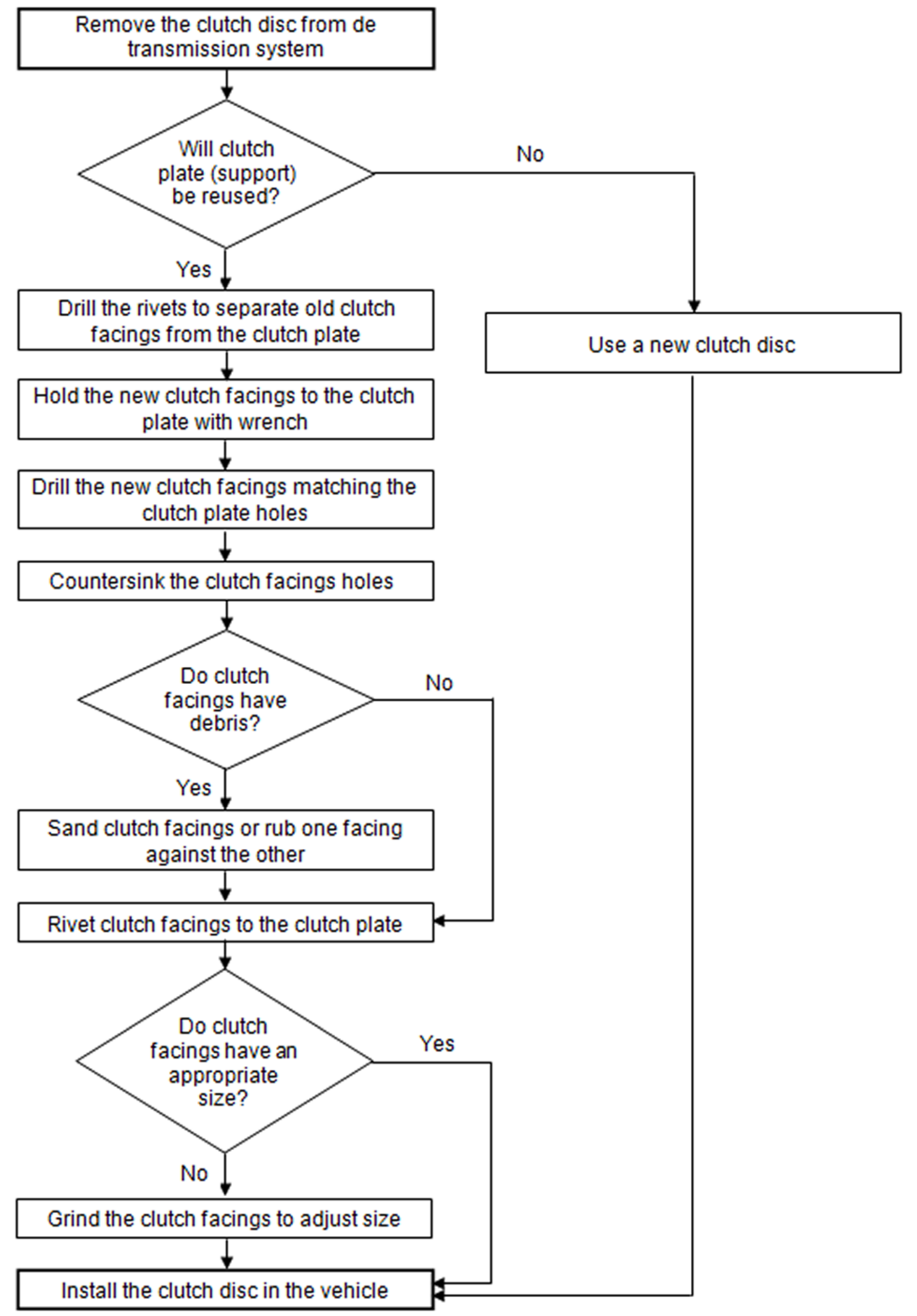

Figure 2. Manipulation process of clutch facings 
Table 2. Phase contrast microscopy equivalent (PCME) 8-hr TWA and 8.5-hr TWA personal asbestos concentrations for workers sampled in Transmission Repair Shop 1.

\begin{tabular}{|c|c|c|c|c|c|c|c|}
\hline \multirow[b]{2}{*}{$\begin{array}{l}\text { Worker - } \\
\text { Day }\end{array}$} & \multirow{2}{*}{$\begin{array}{l}\text { Number } \\
\text { of } \\
\text { sampling } \\
\text { windows }\end{array}$} & \multirow{2}{*}{$\begin{array}{l}\text { Total } \\
\text { sampling } \\
\text { time } \\
(\min )\end{array}$} & \multirow{2}{*}{$\begin{array}{l}\text { TWA PCME } \\
\text { concentration } \\
\text { using total } \\
\text { sampling time } \\
\left(\mathrm{f} / \mathrm{cm}^{3}\right)\end{array}$} & \multicolumn{2}{|c|}{$\begin{array}{l}\text { U.S. OSHA STANDARD } \\
\left(0.1 \mathrm{f} / \mathrm{cm}^{3} \text { for } 8 \text {-hr TWA }\right)\end{array}$} & \multicolumn{2}{|c|}{$\begin{array}{l}\text { COLOMBIAN STANDARD } \\
\left(0.091 \mathrm{f} / \mathrm{cm}^{3} \text { for } 8.5-\mathrm{hr} \text { TWA }\right)\end{array}$} \\
\hline & & & & $\begin{array}{l}\text { Time assumed } \\
\text { with } 0 \mathrm{f} / \mathrm{cm}^{3} \text { to } \\
\text { complete 8-hr } \\
\text { TWA (min) }\end{array}$ & $\begin{array}{c}\text { 8-hr TWA } \\
\text { PCME } \\
\text { concentration } \\
\left(\mathrm{f} / \mathrm{cm}^{3}\right)\end{array}$ & $\begin{array}{l}\text { Time assumed } \\
\text { with } 0 \mathrm{f} / \mathrm{cm}^{3} \text { to } \\
\text { complete } 8.5- \\
\text { hr TWA (min) }\end{array}$ & $\begin{array}{c}\text { 8.5-hr TWA } \\
\text { PCME } \\
\text { concentration } \\
\left(\mathrm{f} / \mathrm{cm}^{3}\right)\end{array}$ \\
\hline R1 - Day 1 & 11 & 508 & 0.103 & - & $0.108^{a, b}$ & 2 & $0,103^{a, c}$ \\
\hline R1 - Day 2 & 5 & 495 & 0.064 & - & 0.066 & 15 & 0.062 \\
\hline R1 - Day 3 & 4 & 270 & 0.042 & 210 & 0.024 & 240 & 0.022 \\
\hline R2 - Day 1 & 12 & 510 & 0.107 & - & $0.111^{b}$ & 0 & $0.107^{c}$ \\
\hline R2 - Day 2 & 13 & 480 & 0.077 & 0 & $0.077^{\mathrm{a}}$ & 30 & $0.073^{a}$ \\
\hline R2 - Day 3 & 6 & 263 & 0.088 & 217 & 0.048 & 247 & 0.046 \\
\hline W1 - Day 1 & 2 & 533 & 0.013 & - & $0.013^{d}$ & - & $0.013^{\mathrm{e}}$ \\
\hline W1 - Day $2^{f}$ & 7 & 553 & 0.012 & - & $0.014^{a}$ & - & $0.012^{a}$ \\
\hline W1 - Day 3 & 1 & 285 & 0.010 & 195 & 0.006 & 225 & $0.006^{g}$ \\
\hline
\end{tabular}

R1: Riveter 1, R2: Riveter 2, W1: worker 1.

${ }^{a}$ TWA PCME concentration includes sampling window(s) with PCM concentrations <LOD. Total fibers/asbestos fibers ratio was multiplied by one-half of the LOD for sampling window(s) with PCM concentrations <LOD.

${ }^{\mathrm{b}}$ 8-hr TWA PCME concentration not in compliance with OSHA PEL of $0.1 \mathrm{f} / \mathrm{cm}^{3}$.

c 8.5-hr TWA PCME concentration not in compliance with Colombian PLVc of $0.091 \mathrm{f} / \mathrm{cm}^{3}$.

d 8-hr TWA PCME concentration calculated using the worst 8-hr of the work shift, according with the U.S. OSHA Technical Manual (OSHA, 2008).

e Samples were collected during 533 minutes this day. TWA PCME concentration was estimated for the total sampling time, and compared against the Colombian PLVc of $0.085 \mathrm{f} / \mathrm{cm}^{3}$.

${ }^{f}$ TWA estimation includes concentrations from samples W1 Day2 P2 and W1 Day2 ST2, in which the conducting extension cowl were accidentally opened at the end of the sample collection. Cowls were immediately closed and the filter always remained in the cowl.

${ }^{g}$ Samples were collected during 553 minutes this day. TWA PCME concentration was estimated for the total sampling time, and compared against the Colombian PLVc of $0.080 \mathrm{f} / \mathrm{cm}^{3}$.

Table 3. Phase contrast microscopy equivalent (PCME) 8-hr TWA and 9-hr TWA personal asbestos concentrations for workers sampled in Transmission Repair Shop 2.

\begin{tabular}{|c|c|c|c|c|c|c|c|}
\hline \multirow[b]{2}{*}{$\begin{array}{l}\text { Worker - } \\
\text { Day }\end{array}$} & \multirow{2}{*}{$\begin{array}{l}\text { Number } \\
\text { of } \\
\text { sampling } \\
\text { windows }\end{array}$} & \multirow{2}{*}{$\begin{array}{l}\text { Total } \\
\text { sampling } \\
\text { time } \\
\text { (min) }\end{array}$} & \multirow{2}{*}{$\begin{array}{l}\text { TWA PCME } \\
\text { concentration } \\
\text { using total } \\
\text { sampling time } \\
\left(\mathrm{f} / \mathrm{cm}^{3}\right)\end{array}$} & \multicolumn{2}{|c|}{$\begin{array}{l}\text { U.S. OSHA STANDARD } \\
\left(0.1 \mathrm{f} / \mathrm{cm}^{3} \text { for } 8-\mathrm{hr} \text { TWA }\right)\end{array}$} & \multicolumn{2}{|c|}{$\begin{array}{l}\text { COLOMBIAN STANDARD } \\
\left(0.083 \mathrm{f} / \mathrm{cm}^{3} \text { for } 9-\mathrm{hr} \text { TWA }\right)\end{array}$} \\
\hline & & & & $\begin{array}{c}\text { Time assumed } \\
\text { with } 0 \mathrm{f} / \mathrm{cm}^{3} \text { to } \\
\text { complete 8-hr } \\
\text { TWA (min) }\end{array}$ & $\begin{array}{c}\text { 8-hr TWA } \\
\text { PCME } \\
\text { concentration } \\
\left(\mathrm{f} / \mathrm{cm}^{3}\right)\end{array}$ & $\begin{array}{c}\text { Time assumed } \\
\text { with } 0 \mathrm{f} / \mathrm{cm}^{3} \text { to } \\
\text { complete } 9 \text {-hr } \\
\text { TWA (min) }\end{array}$ & $\begin{array}{c}\text { 9-hr TWA } \\
\text { PCME } \\
\text { concentration } \\
\left(\mathrm{f} / \mathrm{cm}^{3}\right)\end{array}$ \\
\hline R3 - Day 1 & 7 & 461 & 0.159 & 19 & $0.153^{a, b, c}$ & 79 & $0.136^{c, d}$ \\
\hline R3 - Day 2 & 7 & 475 & 0.195 & 5 & $0.193^{a, b, e}$ & 65 & $0.172^{d, e}$ \\
\hline R3 - Day $3^{f}$ & 4 & 479 & 0.024 & 1 & $0.025^{, e}$ & 61 & $0.022^{e}$ \\
\hline R3 - Day 4 & 4 & 513 & 0.032 & - & $0.034^{a}$ & 27 & 0.030 \\
\hline R3 - Day 5 & 5 & 523 & 0.057 & - & $0.061^{\mathrm{a}, \mathrm{e}}$ & 17 & $0.055^{\mathrm{e}}$ \\
\hline
\end{tabular}

R3: Riveter 3.

a 8-hr TWA PCME concentration calculated using the worst 8-hr of the work shift, according with the U.S. OSHA

Technical Manual (OSHA, 2008).

b 8-hr TWA PCME concentration not in compliance with OSHA PEL of $0.1 \mathrm{f} / \mathrm{cm}^{3}$. 
${ }^{c}$ TWA PCME concentration includes a suspect sample that had a flow drift of $5.4 \%$, with a sampling time of 30 -min and a PCME concentration of $1.084 \mathrm{f} / \mathrm{cm}^{3}$.

${ }^{\mathrm{d}}$ 9-hr TWA PCME concentration not in compliance with the Colombian PLVc of $0.083 \mathrm{f} / \mathrm{cm}^{3}$.

${ }^{\mathrm{e}}$ TWA PCME concentration includes sampling window(s) with PCM concentrations <LOD. Total fibers/asbestos fibers ratio was multiplied by one-half of the LOD for sampling window(s) with PCM concentrations <LOD.

${ }^{f}$ TWA estimation includes concentration from sample R3 Day3 P3, in which the conducting extension cowl was accidentally opened at the end of the sample collection. Cowl was immediately closed and the filter always remained in the cowl.

Table 4 shows the 30-min PCME short-term personal asbestos concentrations and the description of the manipulation or cleaning activities associated with each sample in both TRS. If the sampling window was shorter than $30-\mathrm{min}, 0 \mathrm{f} / \mathrm{cm}^{3}$ was assumed for the remaining time. All the 30-min PCME short-term personal samples collected in TRS1 were below the U.S. OSHA STEL. Two 30-min PCME short-term personal samples collected in TRS2 exceeded the U.S. OSHA STEL of $1 \mathrm{f} / \mathrm{cm}^{3}$. Eleven percent $(11 \%)$ of all the short-term personal samples collected in both shops were above $50 \%$ of the U.S. OSHA STEL.

Table 4. Phase contrast microscopy equivalent (PCME) 30-min short-term personal concentrations of workers sampled in both transmission repair shops (TRS), and description of the activities performed during each sampling window.

\begin{tabular}{|c|c|c|c|c|c|}
\hline $\begin{array}{l}\text { Worker - day - } \\
\quad \text { sample } \\
\text { ST: Short Term }\end{array}$ & $\begin{array}{l}\text { Sampling } \\
\text { time } \\
\text { (min) }\end{array}$ & $\begin{array}{c}\text { TEM } \\
\text { asbestos } \\
\text { concentration } \\
\left(\mathrm{f} / \mathrm{cm}^{3}\right)\end{array}$ & $\begin{array}{l}\text { Chrysotile } \\
\text { fibers counted } \\
\text { (TEM f/F } \\
\text { ratio) }\end{array}$ & $\begin{array}{l}\text { TWA 30-min } \\
\text { PCME } \\
\text { asbestos } \\
\text { concentration } \\
\left(\mathrm{f} / \mathrm{cm}^{3}\right)\end{array}$ & Activities \\
\hline R1 Day1 ST 1 & 32 & 0.239 & $14(1)$ & $0.072^{a}$ & $\begin{array}{l}\text { The worker removed debris from a lathe } \\
\text { with his hand, in dry conditions. }\end{array}$ \\
\hline R1 Day1 ST 2 & 28 & 0.295 & $15(1)$ & $0.120^{\mathrm{b}}$ & $\begin{array}{l}\text { Manipulation }{ }^{d} \text { (including sanding) of two } \\
\text { asbestos-containing passenger vehicle's } \\
\text { clutch facings. }\end{array}$ \\
\hline R1 Day1 ST 3 & 31 & 0.196 & $11(1)$ & $0.021^{a, c}$ & $\begin{array}{l}\text { Unriveting the clutch facings of a heavy } \\
\text { vehicle's clutch disc. Grinding the clutch } \\
\text { plate with emery disc. Manipulation }{ }^{d} \\
\text { (Including sanding) of two asbestos- } \\
\text { containing heavy vehicle's clutch facings. }\end{array}$ \\
\hline R1 Day1 ST 4 & 35 & 0.378 & $24(1)$ & $0.217^{a}$ & $\begin{array}{l}\text { Manipulation }{ }^{d} \text { (Including sanding) of two } \\
\text { asbestos-containing heavy vehicle's clutch } \\
\text { facings. Manipulation }{ }^{d} \text { (Including sanding) } \\
\text { of two asbestos-containing passenger } \\
\text { vehicle's clutch facings. }\end{array}$ \\
\hline R1 Day1 ST 5 & 30 & 0.388 & $21(1)$ & 0.199 & $\begin{array}{l}\text { Manipulation ' (Including sanding) of two } \\
\text { asbestos-containing passenger vehicle's } \\
\text { clutch facings. }\end{array}$ \\
\hline R1 Day1 ST 6 & 33 & 0.519 & $31(1)$ & $0.227^{a}$ & $\begin{array}{l}\text { The worker hit the clutch plate to adjust the } \\
\text { springs of the clutch plate. Manipulation }{ }^{d} \\
\text { (Including sanding) of two asbestos- } \\
\text { containing passenger vehicle's clutch } \\
\text { facings. }\end{array}$ \\
\hline R1 Day1 ST 7 & 30 & 0.166 & $9(1)$ & 0.195 & $\begin{array}{l}\text { Manipulation }{ }^{d} \text { of two asbestos-containing } \\
\text { passenger vehicle's clutch facings. }\end{array}$ \\
\hline R1 Day1 ST 8 & 32 & 0.104 & $6(1)$ & $0.077^{a}$ & $\begin{array}{l}\text { Cleaning activities performed after } \\
\text { sprinkling small amounts of water on the } \\
\text { floor. Sweeping the floor and machines }\end{array}$ \\
\hline
\end{tabular}




\begin{tabular}{|c|c|c|c|c|c|}
\hline $\begin{array}{c}\text { Worker - day - } \\
\text { sample } \\
\text { ST: Short Term }\end{array}$ & $\begin{array}{l}\text { Sampling } \\
\text { time } \\
\text { (min) }\end{array}$ & $\begin{array}{c}\text { TEM } \\
\text { asbestos } \\
\text { concentration } \\
\left(\mathrm{f} / \mathrm{cm}^{3}\right)\end{array}$ & $\begin{array}{l}\text { Chrysotile } \\
\text { fibers counted } \\
\text { (TEM f/F } \\
\text { ratio) }\end{array}$ & $\begin{array}{l}\text { TWA 30-min } \\
\text { PCME } \\
\text { asbestos } \\
\text { concentration } \\
\left(\mathrm{f} / \mathrm{cm}^{3}\right)\end{array}$ & Activities \\
\hline
\end{tabular}

surfaces.

\begin{tabular}{|c|c|c|c|c|c|}
\hline R1 Day2 ST 1 & 32 & 1.017 & $59(1)$ & $0.197^{a}$ & $\begin{array}{l}\text { Manipulation }{ }^{\text {d }} \text { (Including sanding) of two } \\
\text { asbestos-containing heavy vehicle's clutch } \\
\text { facings. The worker removed debris from } \\
\text { the machines with his hand, in dry } \\
\text { conditions. }\end{array}$ \\
\hline R1 Day2 ST 2 & 30 & 0.488 & $27(1)$ & 0.332 & $\begin{array}{l}\text { Manipulation }{ }^{d} \text { of two asbestos-containing } \\
\text { passenger vehicle's clutch facings. Rubbing } \\
\text { one facing against the other to remove the } \\
\text { debris }^{g} \text {. }\end{array}$ \\
\hline R1 Day3 ST 1 & 30 & 0.725 & $40(1)$ & 0.176 & $\begin{array}{l}\text { Manipulation }{ }^{d} \text { of two asbestos-containing } \\
\text { passenger vehicle's clutch facings. }\end{array}$ \\
\hline R1 Day3 ST 2 & 29 & 0.543 & $29(1)$ & $0.164^{b}$ & $\begin{array}{l}\text { Manipulation }{ }^{d} \text { of two asbestos-containing } \\
\text { passenger vehicle's clutch facings. The } \\
\text { worker blew the clutch plate. Cleaning } \\
\text { activities in the shop performed after } \\
\text { sprinkling small amounts of water on the } \\
\text { floor. Sweeping. Emptying the trash can. }\end{array}$ \\
\hline R2 Day1 ST 1 & 30 & 0.511 & $27(1)$ & 0.148 & $\begin{array}{l}\text { Manipulation }{ }^{\mathrm{d}} \text { (Including sanding) of two } \\
\text { asbestos-containing passenger vehicle's } \\
\text { clutch facings. }\end{array}$ \\
\hline R2 Day1 ST 2 & 39 & 0.488 & $33(1)$ & $0.079^{a}$ & $\begin{array}{l}\text { Manipulation }{ }^{d} \text { (Including sanding) of two } \\
\text { asbestos-containing passenger vehicle's } \\
\text { clutch facings. }\end{array}$ \\
\hline R2 Day1 ST 3 & 24 & 0.251 & $11(1)$ & $0.118^{\mathrm{b}}$ & $\begin{array}{l}\text { Painting a clutch plate with spray. } \\
\text { Manipulation }{ }^{d} \text { (Including sanding) of two } \\
\text { asbestos-containing passenger vehicle's } \\
\text { clutch facings. Grinding a clutch plate with } \\
\text { emery disc. Manipulation }{ }^{d} \text { (Including } \\
\text { sanding) of two non-asbestos passenger } \\
\text { vehicle's clutch facings. The worker cleaned } \\
\text { machines with a broom, in dry conditions. }\end{array}$ \\
\hline
\end{tabular}

\begin{tabular}{|c|c|c|c|c|c|}
\hline R2 Day1 ST 4 & 35 & 0.094 & $6(1)$ & $0.133^{a}$ & $\begin{array}{l}\text { Activities were not recorded during this } \\
\text { sampling window. }\end{array}$ \\
\hline \multirow[t]{2}{*}{ R2 Day1 ST 5} & 35 & 0.235 & $15(1)$ & $0.132^{a}$ & $\begin{array}{l}\text { Manipulation }{ }^{d} \text { (Including sanding) of two } \\
\text { asbestos-containing passenger vehicle's } \\
\text { clutch facings. }\end{array}$ \\
\hline & & & & & $\begin{array}{l}\text { Manipulation }{ }^{d} \text { (Including sanding) of two } \\
\text { asbestos-containing heavy vehicle's clutch } \\
\text { facings. }\end{array}$ \\
\hline R2 Day1 ST 6 & 33 & 0.265 & $16(1)$ & $0.123^{a}$ & $\begin{array}{l}\text { Manipulation }{ }^{d} \text { (Including sanding) of four } \\
\text { asbestos-containing passenger vehicle's } \\
\text { clutch facings. Grinding a clutch plate with } \\
\text { emery disc. }\end{array}$ \\
\hline
\end{tabular}




\begin{tabular}{|c|c|c|c|c|c|}
\hline $\begin{array}{l}\text { Worker - day - } \\
\quad \text { sample } \\
\text { ST: Short Term }\end{array}$ & $\begin{array}{l}\text { Sampling } \\
\text { time } \\
\text { (min) }\end{array}$ & $\begin{array}{c}\text { TEM } \\
\text { asbestos } \\
\text { concentration } \\
\left(\mathrm{f} / \mathrm{cm}^{3}\right)\end{array}$ & $\begin{array}{l}\text { Chrysotile } \\
\text { fibers counted } \\
\text { (TEM f/F } \\
\text { ratio) }\end{array}$ & $\begin{array}{l}\text { TWA 30-min } \\
\text { PCME } \\
\text { asbestos } \\
\text { concentration } \\
\left(\mathrm{f} / \mathrm{cm}^{3}\right)\end{array}$ & Activities \\
\hline R2 Day1 ST 7 & 36 & 0.183 & $12(1)$ & $0.126^{a}$ & $\begin{array}{l}\text { Unriveting two old clutch facings of } \\
\text { passenger vehicle. Adjusting two new } \\
\text { facings size with a lathe. Grinding the clutch } \\
\text { plate. Manipulation }{ }^{d} \text { (Including sanding) of } \\
\text { two asbestos-containing passenger } \\
\text { vehicle's clutch facings. }\end{array}$ \\
\hline R2 Day1 ST 8 & 37 & 0.118 & $8(1)$ & $0.049^{a}$ & $\begin{array}{l}\text { Manipulation }{ }^{d} \text { (Including sanding) of two } \\
\text { asbestos-containing passenger vehicle's } \\
\text { clutch facings. Grinding the clutch plate. }\end{array}$ \\
\hline R2 Day1 ST 9 & 32 & 0.103 & $6(1)$ & $0.145^{a}$ & $\begin{array}{l}\text { Manipulation }{ }^{d} \text { (Including sanding and } \\
\text { grinding) of two asbestos-containing } \\
\text { passenger vehicle's clutch facings. }\end{array}$ \\
\hline R2 Day2 ST 1 & 33 & 0.183 & $11(1)$ & $0.123^{a}$ & $\begin{array}{l}\text { Unriveting two passenger vehicle's clutch } \\
\text { facings. The worker used the drill to adjust } \\
\text { the holes size of clutch plate. Grinding and } \\
\text { painting a clutch plate with spray. } \\
\text { Manipulation }{ }^{d} \text { (Including sanding) of four } \\
\text { asbestos-containing passenger vehicle's } \\
\text { clutch facings. The worker removed debris } \\
\text { from the machines with his hand, in dry } \\
\text { conditions. }\end{array}$ \\
\hline R2 Day2 ST 2 & 31 & 0.054 & $3(1)$ & $0.049^{a}$ & $\begin{array}{l}\text { Adjusting the springs of the clutch plate, } \\
\text { washing with gasoline, blowing and painting } \\
\text { the clutch plate with spray. Painting another } \\
3 \text { clutch plates with spray. Drilling, } \\
\text { countersinking and sanding two asbestos- } \\
\text { containing heavy vehicle's clutch facings. } \\
\text { Other worker swept near to R2, in dry } \\
\text { conditions. }\end{array}$ \\
\hline R2 Day2 ST 3 & 29 & 0.134 & $7(1)$ & $0.022^{b, c}$ & $\begin{array}{l}\text { Manipulation }{ }^{d} \text { of two asbestos-containing } \\
\text { heavy vehicle's clutch facings. Washing } \\
\text { with gasoline and painting a clutch plate } \\
\text { with spray. }\end{array}$ \\
\hline R2 Day2 ST 4 & 32 & 0.451 & $26(1)$ & $0.062^{a}$ & $\begin{array}{l}\text { Manipulation 'of two asbestos-containing } \\
\text { heavy vehicle's clutch facings. } \\
\text { Countersinking and sanding two asbestos- } \\
\text { containing passenger vehicle's clutch } \\
\text { facings. Washing with gasoline and painting } \\
\text { a clutch plate with spray. }\end{array}$ \\
\hline R2 Day2 ST 5 & 30 & 0.203 & $11(1)$ & $0.022^{c}$ & $\begin{array}{l}\text { Manipulation ' (Including sanding) of two } \\
\text { asbestos-containing passenger vehicle's } \\
\text { clutch facings. }\end{array}$ \\
\hline R2 Day2 ST 6 & 34 & 0.259 & $16(1)$ & $0.110^{a}$ & $\begin{array}{l}\text { Manipulation }{ }^{d} \text { of two asbestos-containing } \\
\text { heavy vehicle's clutch facings. The worker } \\
\text { cleaned a clutch plate with a brush, in dry } \\
\text { conditions. }\end{array}$ \\
\hline R2 Day2 ST 7 & 29 & 0.095 & $5(1)$ & $0.205^{b}$ & $\begin{array}{l}\text { Manipulation }{ }^{d} \text { (Including sanding and } \\
\text { grinding) of two asbestos-containing }\end{array}$ \\
\hline
\end{tabular}




\begin{tabular}{|c|c|c|c|c|c|}
\hline $\begin{array}{l}\text { Worker - day - } \\
\quad \text { sample } \\
\text { ST: Short Term }\end{array}$ & $\begin{array}{l}\text { Sampling } \\
\text { time } \\
\text { (min) }\end{array}$ & $\begin{array}{c}\text { TEM } \\
\text { asbestos } \\
\text { concentration } \\
\left(\mathrm{f} / \mathrm{cm}^{3}\right)\end{array}$ & $\begin{array}{l}\text { Chrysotile } \\
\text { fibers counted } \\
\text { (TEM f/F } \\
\text { ratio) }\end{array}$ & $\begin{array}{l}\text { TWA 30-min } \\
\text { PCME } \\
\text { asbestos } \\
\text { concentration } \\
\left(\mathrm{f} / \mathrm{cm}^{3}\right)\end{array}$ & Activities \\
\hline & & & & & passenger vehicle's clutch facings. \\
\hline R2 Day2 ST 8 & 30 & 0.431 & $24(1)$ & 0.186 & $\begin{array}{l}\text { Manipulation }{ }^{d} \text { of two asbestos-containing } \\
\text { heavy vehicle's clutch facings. }\end{array}$ \\
\hline R2 Day2 ST 9 & 31 & 0.282 & $16(1)$ & $0.093^{a}$ & $\begin{array}{l}\text { Manipulation }{ }^{d} \text { of two asbestos-containing } \\
\text { passenger vehicle's clutch facings. } \\
\text { Adjusting the clutch facings size with a } \\
\text { lathe. }\end{array}$ \\
\hline R2 Day2 ST 10 & 31 & 0.088 & $5(1)$ & $0.078^{a}$ & $\begin{array}{l}\text { Manipulation }{ }^{d} \text { of two non-asbestos heavy } \\
\text { vehicle's clutch facings. }\end{array}$ \\
\hline R2 Day3 ST 1 & 30 & 0.276 & $15(0.94)$ & 0.139 & $\begin{array}{l}\text { Manipulation }{ }^{d} \text { of two asbestos-containing } \\
\text { passenger vehicle's clutch facings. Grinding } \\
\text { the clutch plate. }\end{array}$ \\
\hline R2 Day3 ST 2 & 34 & 0.311 & $19(1)$ & $0.080^{a}$ & $\begin{array}{l}\text { Manipulation }{ }^{d} \text { of two asbestos-containing } \\
\text { heavy vehicle's clutch facings. }\end{array}$ \\
\hline R2 Day3 ST 3 & 25 & 0.290 & $13(1)$ & $0.094^{b}$ & $\begin{array}{l}\text { Activities were not recorded during this } \\
\text { sampling window. }\end{array}$ \\
\hline R2 Day3 ST 4 & 48 & 0.302 & $26(0.96)$ & $0.092^{a}$ & $\begin{array}{l}\text { Manipulation }{ }^{\text {d }} \text { of two asbestos-containing } \\
\text { passenger vehicle's clutch facings. Other } \\
\text { worker was sweeping close to him after } \\
\text { sprinkling small amounts of water on the } \\
\text { floor. Ventilation system was operating. }\end{array}$ \\
\hline W1 Day2 ST 1 & 30 & 0.222 & $12(1)$ & 0.153 & $\begin{array}{l}\text { Manipulation }{ }^{d} \text { of two asbestos-containing } \\
\text { passenger vehicle's clutch facings. }\end{array}$ \\
\hline W1 Day2 ST $2^{\mathrm{e}}$ & 32 & 0.018 & $1(1)$ & $0.021^{a}$ & $\begin{array}{l}\text { Manipulation }{ }^{d} \text { of two non-asbestos } \\
\text { passenger vehicle's clutch facings. }\end{array}$ \\
\hline W1 Day2 ST 3 & 32 & 0.316 & $18(1)$ & $0.021^{a}$ & $\begin{array}{l}\text { Manipulation }{ }^{d} \text { of two asbestos-containing } \\
\text { passenger vehicle's clutch facings. }\end{array}$ \\
\hline R3 Day1 ST 1 & 35 & 0.796 & $48(1)$ & $0.649^{a}$ & $\begin{array}{l}\text { Manipulation }{ }^{d} \text { (Including sanding and } \\
\text { grinding) of two asbestos-containing } \\
\text { passenger vehicle's clutch facings. Grinding } \\
\text { the clutch disc with emery disc. The worker } \\
\text { hit the clutch plate to adjust the springs. } \\
\text { The worker hit the clutch facings to remove } \\
\text { the debris. }\end{array}$ \\
\hline R3 Day1 ST 2 & 30 & 3.658 & $103(1)$ & $1.084^{\dagger}$ & $\begin{array}{l}\text { Manipulation }{ }^{d} \text { (Including sanding and } \\
\text { grinding) of two asbestos-containing clutch } \\
\text { facings. Rubbing the facings }{ }^{h} \text {. Grinding the } \\
\text { clutch plate. }\end{array}$ \\
\hline R3 Day1 ST 3 & 30 & 0.426 & $23(1)$ & 0.223 & $\begin{array}{l}\text { Manipulation }{ }^{d} \text { (Including sanding and } \\
\text { grinding) of two asbestos-containing } \\
\text { passenger vehicle's clutch facings. Rubbing } \\
\text { the facings }{ }^{g} \text {. }\end{array}$ \\
\hline R3 Day1 ST4 & 29 & 0.262 & $13(0.93)$ & $0.188^{b}$ & Sanding and grinding a clutch plate. \\
\hline
\end{tabular}




\begin{tabular}{|c|c|c|c|c|c|}
\hline $\begin{array}{l}\text { Worker - day - } \\
\quad \text { sample } \\
\text { ST: Short Term }\end{array}$ & $\begin{array}{l}\text { Sampling } \\
\text { time } \\
\text { (min) }\end{array}$ & $\begin{array}{c}\text { TEM } \\
\text { asbestos } \\
\text { concentration } \\
\left(\mathrm{f} / \mathrm{cm}^{3}\right)\end{array}$ & $\begin{array}{l}\text { Chrysotile } \\
\text { fibers counted } \\
\text { (TEM f/F } \\
\text { ratio) }\end{array}$ & $\begin{array}{l}\text { TWA 30-min } \\
\text { PCME } \\
\text { asbestos } \\
\text { concentration } \\
\left(\mathrm{f} / \mathrm{cm}^{3}\right)\end{array}$ & Activities \\
\hline & & & & & $\begin{array}{l}\text { Unriveting two asbestos-containing } \\
\text { passenger vehicle's clutch facings. }\end{array}$ \\
\hline R3 Day2 ST 1 & 40 & 0.454 & $34(1)$ & $0.403^{a}$ & $\begin{array}{l}\text { Cleaning activities of the shop except the } \\
\text { manipulation area. Manipulation }{ }^{d} \text { (Including } \\
\text { sanding and grinding) of two asbestos- } \\
\text { containing clutch facings. Rubbing the } \\
\text { facings }{ }^{g} \text {. }\end{array}$ \\
\hline R3 Day2 ST 2 & 30 & 3.301 & $110(1)$ & $1.653^{\dagger}$ & $\begin{array}{l}\text { Adjusting the facings to the clutch plate size } \\
\text { with a lathe }{ }^{h} \text {. The worker cut the inner } \\
\text { edges of the facings and sanded it. } \\
\text { Manipulation }{ }^{d} \text { (Including sanding) of two } \\
\text { asbestos-containing clutch facings. Rubbing } \\
\text { the facings }{ }^{g} \text {. Adjusting the pressure plate } \\
\text { of the transmission system. }\end{array}$ \\
\hline R3 Day2 ST 3 & 30 & 1.038 & $57(1)$ & 0.559 & $\begin{array}{l}\text { Manipulation }{ }^{d} \text { (Including sanding) of two } \\
\text { asbestos-containing clutch facings. Rubbing } \\
\text { the facings }{ }^{g} \text {. Grinding and brushing the } \\
\text { clutch disc to remove the debris. }\end{array}$ \\
\hline R3 Day3 ST 1 & 38 & 0.549 & $39(1)$ & $0.283^{a}$ & $\begin{array}{l}\text { Manipulation }{ }^{\mathrm{d}} \text { (Including sanding) of two } \\
\text { asbestos-containing passenger vehicle's } \\
\text { clutch facings. Grinding the clutch plate. } \\
\text { Rubbing the facings }{ }^{g} \text {. }\end{array}$ \\
\hline R3 Day4 ST 1 & 34 & 0.391 & $23(1)$ & $0.387^{a}$ & $\begin{array}{l}\text { Manipulation }{ }^{d} \text { (Including sanding and } \\
\text { grinding) of two asbestos-containing clutch } \\
\text { facings. Rubbing the facings }{ }^{g} \text {. }\end{array}$ \\
\hline R3 Day5 ST 1 & 37 & 0.015 & $1(1)$ & $0.323^{a}$ & $\begin{array}{l}\text { Cleaning activities performed in dry } \\
\text { conditions. Removing dust of the machines } \\
\text { with the broom. Putting wood dust above oil } \\
\text { stains on the floor. Sweeping the shop, } \\
\text { except the manipulation area, in dry } \\
\text { conditions. }\end{array}$ \\
\hline R3 Day5 ST 2 & 32 & 0.598 & $34(1)$ & $0.460^{a}$ & $\begin{array}{l}\text { Manipulation }{ }^{d} \text { (Including sanding and } \\
\text { grinding) of two asbestos-containing } \\
\text { passenger vehicle's clutch facings. }\end{array}$ \\
\hline
\end{tabular}

R1: Riveter 1 (TRS1), R2: Riveter 2 (TRS1), W1: Worker 1 (TRS1), R3: Riveter 3 (TRS2); ST: Short term personal sample.

a Sampling window greater than $30 \mathrm{~min}$. 30-min TWA concentration equal to the sampling time concentration

${ }^{b}$ Sampling window below $30 \mathrm{~min}$. Unsampled time was assumed as $0 \mathrm{f} / \mathrm{cm}^{3}$ to calculate 30 -min TWA concentration,

${ }^{c}$ PCM concentration <LOD. Total fibers/asbestos fibers ratio was multiplied by one-half of the LOD to estimate PCME concentration.

${ }^{\mathrm{d}}$ Manipulation activities include: Unriveting, drilling, countersinking, and riveting clutch facings.

e Suspect sample. The cassette was accidentally opened in the shop after sampling

${ }^{f} 30$-min short-term personal sample above U.S. OSHA STEL of $1 \mathrm{f} / \mathrm{cm}^{3}$

${ }^{g}$ The riveter rubbed one facing against the other to remove the debris

${ }^{\mathrm{h}}$ The lathe in TRS2 was located at $0.5 \mathrm{~m}$ from the filter

Table 5 summarizes statistical information of the 8-hr TWA and 30-min PCME short-term asbestos concentrations of personal samples collected in both TRS sampled. 
Table 5. Statistical summary of phase contrast microscopy equivalent (PCME) personal asbestos concentrations found in the Transmission Repair Shops (TRS) sampled.

\begin{tabular}{|c|c|c|c|c|c|c|c|}
\hline \multirow{2}{*}{$\begin{array}{l}\text { Type of } \\
\text { sample }\end{array}$} & \multirow{2}{*}{$\begin{array}{l}\text { Worker } \\
\text { (Shop) }\end{array}$} & \multirow{2}{*}{$\begin{array}{c}\text { Total number } \\
\text { (Number above the } \\
\text { U.S. OSHA PEL or } \\
\text { STEL) }\end{array}$} & \multicolumn{5}{|c|}{ PCME asbestos concentrations $\left(\mathrm{f} / \mathrm{cm}^{3}\right)$} \\
\hline & & & Mean & St. Dev. & Median & Min & $\operatorname{Max}$ \\
\hline \multirow{4}{*}{$\begin{array}{l}\text { 8-hr TWA } \\
\text { Personal } \\
\text { samples }^{\text {a }}\end{array}$} & R1 (TRS1) & $3\left(1^{b}\right)$ & 0.066 & 0.042 & 0.066 & 0.024 & 0.108 \\
\hline & R2 (TRS1) & $3\left(1^{b}\right)$ & 0.079 & 0.032 & 0.077 & 0.048 & 0.111 \\
\hline & R3 (TRS2) & $5\left(2^{b}\right)$ & 0.093 & 0.076 & 0.061 & 0.025 & 0.193 \\
\hline & W1 (TRS1) & $3\left(0^{b}\right)$ & 0.011 & 0.004 & 0.013 & 0.006 & 0.014 \\
\hline \multirow{4}{*}{$\begin{array}{l}\text { Short term } \\
\text { personal } \\
\text { samples }^{c}\end{array}$} & R1 (TRS1) & $12\left(0^{d}\right)$ & 0.172 & 0.088 & 0.195 & 0.021 & 0.332 \\
\hline & R2 (TRS1) & $23\left(0^{d}\right)$ & 0.105 & 0.048 & 0.110 & 0.022 & 0.212 \\
\hline & R3 (TRS2) & $11\left(2^{d}\right)$ & 0.603 & 0.443 & 0.432 & 0.223 & 1.653 \\
\hline & W1 (TRS1) & $3\left(0^{d}\right)$ & 0.065 & 0.076 & 0.021 & 0.021 & 0.153 \\
\hline
\end{tabular}

R1: Riveter 1, R2: Riveter 2, R3: Riveter 3, W1: worker 1

${ }^{a}$ Calculated using the 8-hr TWA PCME asbestos concentrations shown in Table 2 and Table 3 (Column 6).

${ }^{b}$ Values compared against the U.S. OSHA PEL of $0.1 \mathrm{f} / \mathrm{cm}^{3}$.

${ }^{\mathrm{C}}$ Based on the 30-min PCME asbestos concentrations shown in Table 4 (Column 5).

${ }^{d}$ Values compared against the U.S. OSHA STEL of $1 \mathrm{f} / \mathrm{cm}^{3}$.

\section{Area air samples results}

PCM area concentration results: In TRS1, the three 8-hr TWA PCM office area concentrations collected on days 1,2 , and 3 were $0.009 \mathrm{f} / \mathrm{cm}^{3}, 0.002 \mathrm{f} / \mathrm{cm}^{3}$, and $0.005 \mathrm{f} / \mathrm{cm}^{3}$ respectively. The corresponding 8-hr TWA PCM manipulation area concentrations collected on days 1, 2, and 3 were $0.017 \mathrm{f} / \mathrm{cm}^{3}, 0.010 \mathrm{f} / \mathrm{cm}^{3}$, and $0.015 \mathrm{f} / \mathrm{cm}^{3}$ respectively. In TRS2, the 8-hr TWA PCM A1 area concentrations ranged between $0.007 \mathrm{f} / \mathrm{cm}^{3}$ and $0.050 \mathrm{f} / \mathrm{cm}^{3}$ (i.e., collected during 5 days). For A2, the 8-hr TWA PCM area concentrations ranged between $0.006 \mathrm{f} / \mathrm{cm}^{3}$ and $0.183 \mathrm{f} / \mathrm{cm}^{3}$ (i.e., collected during 5 days).

PCME area concentration results: 8-hr TWA PCME area concentrations in TRS2 were estimated for days 1 and 2 in sampling points $A 1(1 \mathrm{~m})$, and $A 2(2 \mathrm{~m})$ (see Figure 1), because on these days personal samples showed high asbestos exposures of the riveter (R3). For this analysis, fiber concentration was assumed as $0 \mathrm{f} / \mathrm{cm}^{3}$ during periods when samples were not collected. One of these 8-hr TWA area concentrations exceeded $0.1 \mathrm{f} / \mathrm{cm}^{3}$ (i.e., A2 day $2=0.183 \mathrm{f} / \mathrm{cm}^{3}$ ), recognizing that area samples should not be used to determine regulatory compliance. The other 8-hr TWA PCME area concentrations (A1 days 1 and 2, and A2 day 1) had quantifiable asbestos concentrations ranging from 0.024 to $0.050 \mathrm{f} / \mathrm{cm}^{3}$.

Comparison of PCME short-term personal and short-term area concentrations: A preliminary analysis was conducted to determine the migration of fibers in the work area during the manipulation activities. For this, during days 1 and 2 short-term 30-min area concentrations were collected in TRS2 at points A1 and A2 while riveter was manipulating asbestos containing products. PCME 30-min A1 concentrations ranged between $0.091 \mathrm{f} / \mathrm{cm}^{3}$ and $0.207 \mathrm{f} / \mathrm{cm}^{3} .30-\mathrm{min}$ PCME A2 concentrations ranged between $0.069 \mathrm{f} / \mathrm{cm}^{3}$ and $1.715 \mathrm{f} / \mathrm{cm}^{3}$. PCME concentration of sample A2 Day2 ST2 exceeded $1 \mathrm{f} / \mathrm{cm}^{3}$. Recognizing that the number of samples is small, no clear patterns associating asbestos concentration with the distance to the manipulation equipment was observed. 


\section{Discussion}

This study describes the manipulation activities of asbestos containing clutch facings that riveters in TRS have to perform when clutch facings are sold detached from the support. In the TRS sampled, most of the clutch facings used contained asbestos. Riveters sampled have to perform manipulation activities including drilling, countersinking, riveting, sanding, and grinding clutch facings, which release asbestos fibers and expose workers. All riveters sampled were exposed to asbestos concentrations that in some occasions were not in compliance with both the U.S. OSHA PEL and the Colombian standard. Moreover, some manipulation activities resulted in asbestos exposures exceeding the U.S. OSHA STEL. Although ready to install clutch discs are commercially available, they are more expensive and were less common in the transmission repair shops sampled.

To the best of our knowledge, this is the first study that reports asbestos exposures on transmission mechanics (i.e., riveters) in low- and middle-income countries. The results obtained in this study are different from the results of the reduced number of studies conducted on this occupational group in high-income countries. In 1999, a study conducted in Sidney, Australia found that during the replacement process of a clutch disc, PCM concentrations were below the Limit of Detection $\left(0.05 \mathrm{f} / \mathrm{cm}^{3}\right)$ (Yeung, et al., 1999). A study from the United States evaluated personal exposures to asbestos among transmission mechanics during activities that included unpacking, repacking and stacking boxes, cleaning asbestos containing clutch discs, and clothes handling. This study found that personal asbestos concentrations were in compliance with the U.S. OSHA PEL and STEL, and reported that the highest exposures were associated with stacking unopened boxes (Jiang, et al., 2008). Another study conducted in the United States in 2003 analyzed asbestos exposures during the removal and replacement of asbestos-containing materials in heavy vehicles (i.e., gaskets, brakes, and clutch parts). In this study, authors reported that the PCME short-term personal asbestos concentrations ranged between $<0.043 \mathrm{f} / \mathrm{cm}^{3}$ and $0.099 \mathrm{f} / \mathrm{cm}^{3}$, and TWA PCME concentrations ranged between $0.011 \mathrm{f} / \mathrm{cm}^{3}$ and $0.052 \mathrm{f} / \mathrm{cm}^{3}$ during different sampling periods (i.e., from 336 to $574 \mathrm{~min}$ ) (Boelter, et al., 2007). Finally, Blake et al. (2008) reported that during the installation of a clutch disc, the 8-hr TWA PCME chrysotile asbestos concentration was $0.0011 \mathrm{f} / \mathrm{cm}^{3}$ (Blake, et al., 2008). All these studies concluded that transmission mechanics are not at excess risk of developing asbestos related diseases (Blake, et al., 2008; Boelter et al., 2003; Jiang, et al., 2008; Yeung, et al., 1999). However, none of the previous studies report the manipulation activities conducted by the riveters sampled in the current study. Thus, a potential explanation for the low asbestos exposures reported in studies conducted in high-income countries involve the fact that in these countries, clutch discs can be directly installed in vehicles without manipulating clutch facings.

As expected, days with the highest number of manipulations resulted in the highest 8-hr TWA PCME personal asbestos concentrations. Focusing on the 8-hr TWA PCME personal asbestos estimates, 29\% (4 out of 14) exceeded both the U.S. OSHA PEL and the Colombian PLVc. Focusing on the PCME 30-min short-term personal samples, 4.1\% (2 out of 49 ) exceeded the U.S. OSHA STEL.

The supervisor in TRS1 (W1) was the only worker sampled who was not exposed to asbestos concentrations above the U.S. OSHA or Colombian standards. This could be explained because this worker rarely manipulated clutch facings, and during sampling days 1 and 3 did not conduct any manipulation activity. However, personal samples of W1 indicate exposure to asbestos fibers. This is important because even at concentrations in compliance with the regulations, there is a risk of developing asbestos related diseases (OSHA, 1995). Similarly to W1, other workers and customers that share work areas with riveters may be exposed to asbestos fibers. 
Riveter 3 in TRS2 had two samples that exceeded the U.S. OSHA STEL. R3 also had the highest 8-hr TWA PCME asbestos concentrations among all workers sampled, exceeding the U.S. OSHA PEL and Colombian PLVc in two of the five days sampled. There are some potential explanations for this. First, based on the activity diaries filled during sampling campaigns, R3 frequently rubbed one clutch facing against the other to eliminate debris, and this activity was often performed close to his respiratory zone. In contrast, riveters in TRS1 used sand paper for this task, and in only one occasion during the sampling campaign, one worker in TRS1 (i.e., R1) rubbed clutch facings (i.e., sample R1 Day2 ST 2, in Table 4). Second, cleaning activities of the manipulation area were uncommon in TRS2, and old clutch facings and damaged clutch discs were disposed on the floor. Thus, asbestos fibers could be re-suspended, creating an additional source of exposure. Finally, TRS2 was a small shop, with a smaller manipulation area and a lower ceiling in comparison to TRS1. Thus, ventilation conditions were worst in TRS2.

There were two 30-min short-term personal samples collected during the manipulation activities of clutch facings that the riveters reported as asbestos free (i.e., R2 Day3 ST 10 and W1 Day2 ST 2 , in Table 4), and no other activity was performed during these sampling windows. However, these samples had asbestos fibers. This phenomenon was also described in a similar study of brake mechanics in Bogotá (Cely-García, et al., 2012). As it was explained by Cely-García et al., the manipulation equipment may have been contaminated with asbestos fibers during previous manipulation activities, and fibers may have been re-suspended. Another potential explanation was that although riveters reported clutch facings as asbestos free, they might have contained asbestos.

Area samples collected in both shops suggest that other workers not involved in the manipulation activities may be exposed to asbestos fibers. One short-term area sample collected at $2 \mathrm{~m}$ from the manipulation equipment was above the personal sample collected on the riveter performing the manipulation. However, the concentrations of both samples were similar (Personal sample R3 Day2 ST $2=1.653 \mathrm{f} / \mathrm{cm}^{3}$, area sample A2 Day2 ST $2=1.715 \mathrm{f} / \mathrm{cm}^{3}$ ). These samples were collected while the riveter (R3) was cutting the edges of two clutch facings, and then sanding and grinding them. Because of the location of the manipulation equipment and the area sample in relation to the door, that was the only ventilation of the TRS, one potential explanation is that the wind may have blown the fibers away from the manipulation equipment (i.e., and the riveter) towards the area sample, and may have also re-suspended some fibers.

Workers in shops sampled used personal protection equipment (PPE) not designed for asbestos protection (i.e., respirators and clothes). The TRS also lacked adequate ventilation systems. TRS2 did not have any ventilation system, and the extraction hood of TRS1 was operated in rare occasions. Moreover, PPE are at the bottom in the hierarchy of occupational control options, and other alternatives, such as source interventions, should be prioritized when trying to reduce the risks of these workers.

From an industrial hygiene perspective, the best option to eliminate the risk of asbestos exposure among transmission mechanics would be to produce asbestos free clutch facings. Another option, at a lower level in the hierarchy of controls, would be to commercialize ready to install clutch disks; in TRS2 a clutch disk ready to install was used in one occasion, which did not require any manipulation. A third option, also at a lower level in the hierarchy of controls, would be to paste the clutch facings to the clutch plate, instead of riveting them. However, this option was not available in the TRS sampled.

Recognizing that more studies are needed to improve our understanding of asbestos exposures among mechanics that manipulate asbestos containing products, the results for transmission 
mechanics observed in the current study suggest that they experience higher exposures in comparison to brake mechanics sampled in another study (Cely-García, et al., 2012).

The findings of this study confirm the importance of being cautious when translating the results of occupational studies from high income to low- and middle-income countries. The working conditions, characteristics of the products used, tasks performed by workers, workers training, and the enforcement of regulations to protect workers may have major differences between countries, even when comparing the same occupations.

\section{CONCLUSIONS}

Although the workers in the TRS sampled reported that the number of clutch facings manipulations has decreased over time, the exposure concentrations found are extremely high. Thus, this group of transmission mechanics is at excess risk of developing asbestos related diseases. Furthermore, workers that do not manipulate clutch facings may be exposed to high asbestos concentrations in the workplace. The adverse working conditions of riveters, the need to manipulate asbestos containing clutch facings because they are sold separated from the clutch plate, the lack of training on the risks resulting from working with asbestos containing products, and the absence of proper engineering controls and PPE, raises serious concerns about the potential implications that all these factors may have on the respiratory health of these workers. Similarly to what we have found in Colombia, workers in other developing countries may be experiencing unacceptable occupational risks resulting from asbestos exposure. Thus, it is important to expand our knowledge regarding the risks resulting from the continuous use of asbestos containing products worldwide. The authors strongly recommend that the health, environmental, and labour authorities in Colombia should seriously consider restricting or banning the production and use of asbestos containing products in the country.

\section{REFERENCES}

Blake, C. L., Dotson, G. S. \& Harbison, R. D., 2008. Evaluation of asbestos exposure within the automotive repair industry: A study involving removal of asbestos-containig body sealants and drive clutch replacement. Regulatory Toxicology and Pharmacology, pp. 324-331.

Boelter, F. W., Spencer, J. W. \& Simmons, C. E., 2007. Heavy Equipment Maintenance exposure Assessment: Using a Time-Activity Model to Estimate Surrogate Values for Replacement of Missing Data. Journal of Occupational and Environmental Hygiene, pp. 525-537.

Cely-García, M. F., Sánchez, M., Breysse, P. N. \& Ramos-Bonilla, J. P., 2012. Personal Exposures to Asbestos Fibers During Brake Maintenance of Passenger Vehicles. Annals of Ocupational Hygiene.

Cohen, H. J. \& Van Orden, D. R., 2008. Asbestos Exposures of Mechanics Performing Clutch Service on motor vehicles. Journal of Occupational and Environmental Hygiene, pp. 148 - 156.

Forensic Analitical Laboratories, 2013. Personal comunication. s.I.:s.n.

IARC, 1998. Asbestos. Summary of Data Reported and Evaluation. IARC Monographs on the Evaluation of Carcinogenic Risks to Humans.. IARC Monographs on the Evaluation of Carcinogenic Risks to Humans, Volume 14.

ISO, 1999. ISO 13794. Ambient air. Determination of asbestos fibres. Indirect-transfer transmission electron microscopy method.

Jiang, G. C. et al., 2008. A study of airborne chrysotile concentrations associated with handling, unpacking, and repacking boxes of automobile clutch discs. Regulatory Toxicology and

Pharmacology, pp. 87-97. 
Ministerio de Salud y Protección Social (MSPS), 2011. Resolución 007 de 2011 Por la cual se adopta el Reglamento de Higiene y Seguridad del Crisotilo y otras Fibras de uso similar.. Bogotá: Ministerio de Salud y Protección Social.

NIOSH, 1975. Current Intelligence Bulletin 5: Asbestos Exposure During Servicing of Motor Vehicle Brake and Clutch Assemblies. [Online]

Available at: http://www.cdc.gov/niosh/docs/1970/78127_5.html

[Accessed 19 december 2013].

NIOSH, 1994a. Method 7400. Asbestos and other fibers by PCM. Manual of Analytical Methods. Fourth Ed. [Online]

Available at: http://www.cdc.gov/niosh/docs/2003-154/pdfs/7400.pdf

[Accessed 19 december 2013].

NIOSH, 1994b. Method 7402. Asbestos by TEM. Manual of Analytical Methods. Fourth Ed.

[Online]

Available at: http://www.cdc.gov/niosh/docs/2003-154/pdfs/7402.pdf

[Accessed 2013 december 2013].

OMS, 2004. Chapter 21: Selected occupational risk factors. Comparative Quantification of Health Risks, Volume 2.

OSHA, 1995. OSHA 3095 (Revised). Asbestos Standard For General Industry. [Online]

Available at: https://www.osha.gov/Publications/osha3095.pdf

[Accessed 19 december 2013].

OSHA, 2008. Personal sampling for air contaminants. OSHA Technical Manual (OTM). Section II: Chapter 1.

OSHA, 2013. Asbestos. Standard number 1910.1001.. [Online]

Available at:

https://www.osha.gov/pls/oshaweb/owadisp.show_document?p_table=STANDARDS\&p_id=9995 [Accessed 19 december 2013].

Pierce, J. S., McKinley, M. A. \& Paustenbach, D. J., 2008. An Evaluation of Reported No-Effect Chrysotile Asbestos Exposures for lung Cancer and Mesothelioma. Critical Reviews in Toxicology, pp. 191-214.

Thompson, S. K. \& Mason, E., 2002. Abestos: Mineral and fibers. Chemical Health and safety, July - August, Volume 9, pp. 21 - 23.

Yeung, P., Patience, K., Apthorpe, L. \& Willcocks, D., 1999. An Australian Study to Evaluate Worker Exposure to Chrysotile in the Automotive Service Industry. Applied Occupational and Environmental Hygiene, pp. 449-458. 